\title{
Efficiency indices and indicators of poor performance among emerging small-scale pig farmers in the Limpopo Province, South Africa
}

\begin{abstract}
Authors:
Japhta M. Mokoele ${ }^{1,2}$

B. Tom Spencer ${ }^{1}$

Leo A.M.G. van Leengoed ${ }^{1,3}$

Folorunso O. Fasina ${ }^{1}$

Affiliations:

${ }^{1}$ Department of Production

Animal Studies, University of

Pretoria, South Africa

${ }^{2}$ Limpopo Department of

Agriculture, Limpopo, South

Africa
\end{abstract}

${ }^{3}$ Department of Farm Anima Health, Utrecht University,

The Netherlands

Correspondence to:

Folorunso Fasina

Email:

dayo.fasina@up.ac.za

Postal address:

Private Bag X04,

Onderstepoort Post Office,

South Africa

Dates:

Received: 31 Mar. 2014

Accepted: 05 June 2014

Published: 12 Nov. 2014

How to cite this article: Mokoele, J.M., Spencer, B.T., Van Leengoed, L.A.M.G. \& Fasina, F.O., 2014, 'Efficiency indices and indicators of poor performance among emerging small-scale pig farmers in the Limpopo Province, South Africa', Onderstepoort Journal of Veterinary Research 81(1), Art. \#774, 12 pages. http:// dx.doi.org/10.4102/ojvr. v81i1.774

\section{Copyright:}

(C) 2014. The Authors.

Licensee: AOSIS

OpenJournals. This work

is licensed under the

Creative Commons

Attribution License.

Read online:

Scan this $Q R$ code with your smart phone or mobile device to read online.
Limpopo is a very important area for pig production in terms of animal populations and contributions to transboundary animal disease spread. Emerging small-scale pig farmers (ESSPF) are being encouraged to establish operations and spread in South Africa; however, for these farmers to perform optimally, they need to understand the basics of animal agriculture and contribute to enhancing biosecurity and efficient production systems. In the present study, the limitations to efficient production amongst ESSPF were evaluated and some improvements were suggested. It was found that the ESSPF are dominated by males and include a large percentage of older persons. A total of $26.54 \%$ of these farmers have postmatriculation qualifications. Undefined and indigenous breeds still dominate their animal genetics. The animal health technicians are the preferred channels by which farmers report diseases to the authorities (52.47\%) and only one out of five $(20.37 \%)$ will preferably report a disease situation direct to a veterinarian. These farmers do not vaccinate their stock, and knowledge of biosecurity is poor. Antimicrobials, especially tetracyclines, are abused. Animals that are slaughtered within the community or sold at local sale points, pension pay stations and auction markets are likely candidates for disease spread. It is recommended that the younger generations are retained and incentivised in animal agriculture. Improved training on management, health, biosecurity and better market access must be provided for the ESSPF, whilst efforts should made to consolidate these farmers into small cooperatives. The current government agricultural support system will need to be reworked to benefit the resource-poor farmers. Collaborative efforts in disease reporting and management among veterinarians, animal health technicians and extension officers will become necessary. Finally, the creation of a progressive quality grading system for ESSPF should be planned by the industry and this should be attached to a reward system that will encourage these farmers to target good farming practice.

\section{Introduction}

Pigs are of high economic importance, especially among the poor. They contribute to human nutrition, food security, poverty alleviation, enhanced livelihood and creation of employment for the rural community (Antwi \& Seahlodi 2011; Dietze 2011; Mergenthaler, Weinberger \& Qaim 2009). In addition, they provide a less-expensive source of animal protein for urban diets compared with cattle, sheep and goats (Ironkwe \& Amefule 2008). Whilst pig farming, as part of animal agriculture, is central to the development of rural farmers, the real contribution of emerging small-scale pig farmers (ESSPF) to the rural economy is not well assessed and somewhat doubtful. These economic contributions by ESSPF are constrained by management, health, housing, feeding and marketing constraints (Antwi \& Seahlodi 2011; Chikazunga et al. 2007).

In South Africa, it is suggested that there were approximately 125000 production sows in 2010/2011, with approximately 100000 sows being held commercially and the remaining 25000 being kept by small-scale farmers. The South African pork industry contributes around $2.15 \%$ to the primary agricultural sector, and whilst 2616000 pigs were slaughtered in 2011, the total pork production was put at 203375 tonnes in cold dressed mass (Food and Agriculture Organization Corporate Statistical Database [FAOSTAT] 2014).

Limpopo is a major pig-producing province in South Africa and, in 2011, contributed approximately $24.00 \%$ of the total recorded pig production (Department of Agriculture, Forestry and Fisheries [DAFF] 2012). Only about 11700 of all the sows in the province are registered as commercial sows and there is a widespread distribution of non-registered and disorganised medium-scale and smallscale pig farms. In view of its location and poorly controlled boundaries with other countries, 
previous studies have indicated that Limpopo has played a key role in some transboundary animal disease disseminations and is responsible almost exclusively for new introductions of African swine fever into South Africa (Boshoff et al. 2007). Since all the index cases, to date, of outbreaks of African swine fever in South Africa have originated from Limpopo and the majority of these outbreaks were linked with smallscale pig farms, it is critical to understand the management and production systems of this category of farms in order to effectively carry out proactive disease prevention and management. The present study was conducted in order to collect basic management and health parameters from ESSPF in Limpopo, so that their production efficiency and contributions in terms of biosecurity and health could be evaluated.

\section{Materials and methods}

\section{Study area and data collection}

Five districts in Limpopo province were studied, namely: Sekhukhune, Capricorn, Waterberg, Vhembe and Mopani (Figure 1). These districts have partially documented records $(n=85)$ of ESSPF; Limpopo's Department of Agriculture is in the process of fully documenting the records of these pig farmers. This will enable targeted interventions in terms of infrastructure development, veterinary extension services, and production and marketing inputs to be carefully planned to assist these farmers. A purposive sampling method was used to select $\operatorname{ESSPF}(n=185)$ from the study sites, including the 85 smallscale pig farmers enlisted on Limpopo's Department of Agriculture list and an additional 100 farms that fall within this category but were not listed. The expansion of the list beyond the department list became necessary because the preliminary data from the field suggested that there were many unlisted ESSPF in the province (Steyn et al. 1994). The inclusion criterion for the present study was pig farms with $\leq 50$ sows, located within the five districts of Limpopo, that have been active in pig production for at least one year. A participatory research model approach was used (Raman, Sanghi \& Chambers 1989; Thrusfield 1995).

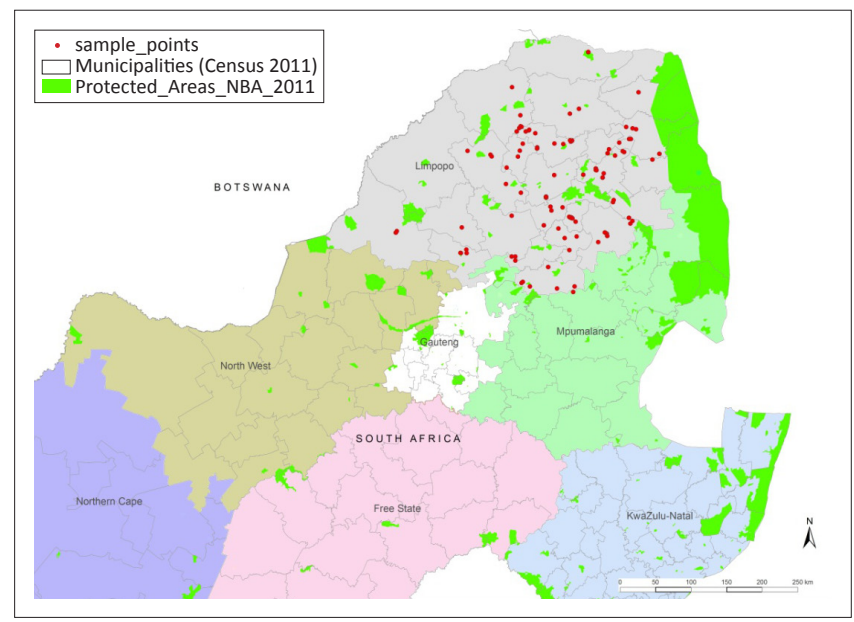

Source: Authors' own construction

FIGURE 1: Map of Limpopo, showing study sites 2012-2013.

\section{Data collection and management}

Based on available literature, expert opinions and primary objectives of the presentstudy, a semi-structured questionnaire (see Appendix 1 for content) was designed at the Department of Production Animal Studies, University of Pretoria. This was pilot tested amongst veterinary students $(n=12)$ and a few extension veterinarians $(n=2)$. The questionnaire was later reviewed and validated during organised consultative forums by selected pig veterinarians in the field, the Research Committees of Limpopo Department of Agriculture and the Faculty of Veterinary Science, University of Pretoria, as well as state veterinarians and animal health technicians of the Limpopo Department of Agriculture. The instrument was used to collect data from the selected participants using a participatory method, as described by Thrusfield (1995). A total of 185 questionnaires were collected from the field, but 20 were filtered out due to missing values and inconsistent data. Another respondent was removed because he had increased his herd size to a 150 sow unit. A total of 164 respondents $(88.65 \%)$ were included in the analysis. The data from completed questionnaires were coded, captured and filtered using a Microsoft Excel ${ }^{\circledR}$ (Microsoft, USA) spreadsheet, and descriptive statistics were performed. The analyses performed included: proportional percentages; measures of central tendencies; percentiles and graphs of farm characteristics; production parameters; management and health parameters; and operational efficiencies using STATA v9.0 (Stata Corporation, Lakeway Drive, College Station, Texas, USA). Efficiency indices for piglets weaned per sow and for average days to oestrus were calculated by dividing the category mean by mean total number of sows for the category. Correlation coefficients were calculated for farm parameters that were thought to influence one another in the analysed data.

\section{Results}

Male farmers represented the majority of the participating respondents $(76.83 \%)$, which is a reflection of the population structure amongst the ESSPF (Table 1a). Similarly, the farmers who were $\geq 46$ years old were $78.53 \%$ of the total respondents; $5.52 \%$ were $\leq 35$ years and $15.95 \%$ were $36-45$ years old. In addition, a total of $77.78 \%$ of the respondents were married (Table 1a). The majority of the farmers interviewed $(63.80 \%)$ were engaged full time in their pig farming activities, whilst only $26.90 \%$ were involved part time.

It was noted that $26.54 \%$ of the total respondents had postmatriculation qualifications. Although the definition of breeds was based on phenotypic characteristics of the pigs observed on the farms, $61.18 \%$ of the breeds used were indigenous or not well described, $28.29 \%$ were Large White, $10.53 \%$ were Landrace and $7.24 \%$ were Duroc breeds (Table 1a). A total of $2.47 \%$ ESSPF farmers had previously benefited from the Comprehensive Agricultural Support Programme (CASP) of the Limpopo Department of Agriculture. The average 
number of sows per farm was 7.4 and the average number of days for a sow to return to oestrus was 42.9 days after weaning the litter, whilst the number of piglets weaned per sow per year was 4.85 pigs (Table $1 \mathrm{~b}$ ). At this rate there would need to be some 50000 sows (unregistered) in Limpopo to make up half of the $24.00 \%$ of slaughter pigs that are not accounted for by the 11700 registered sows mentioned in the introduction above. It is questionable whether this really is the case.

The majority of the respondents $(92.36 \%)$ did not provide a heat source for their piglets, especially in the cold winter, and this greatly impacted on increased levels of mortalities. In addition, $44.00 \%$ lost piglets primarily due to overlay and hypothermia, whilst $62.67 \%$ claimed that piglets were lost principally to multiple causes (Table 2). The interviewed farmers complained about skin conditions in their herds and approximately $46.84 \%$ of the respondents identified skin diseases (primarily mange) as being the most important disease complex on their farms (Table $2)$. Other disease complexes that were rated lower by the farmers included: reproductive $(12.66 \%)$, enteric $(8.86 \%)$, respiratory $(6.33 \%)$, musculoskeletal $(5.05 \%)$ and mixed infections (39.87\%) (Table 2).

A total of $52.47 \%$ of the ESSPF preferred to report to and use the service of animal health technicians. State veterinarians were the first point of contact for one out of five farmers (20.37\%), and $17.28 \%$ preferred to contact the extension officers first. Knowledge and implementation of biosecurity was poor amongst the surveyed farmers, as only $8.07 \%$ washed their hands before or after farming activities, and only $1.24 \%$ utilised footbaths in their farms. Although $65.84 \%$ indicated that they had built fences, it was noted that these fences were not purpose built for biosecurity and were only extensions of the human accommodations.

Most importantly, 98 (77.00\%) of the farmers did not vaccinate their pigs against major pig diseases, including parvovirus infection, leptospirosis and erysipelas. Terramycin was the most abused drug used by $30.38 \%$ of the responding ESSPF, as no diagnosis was reached before treatment was implemented in most cases.

TABLE 1a: Characteristics of emerging small-scale pig farmers, Limpopo, South Africa.

\begin{tabular}{|c|c|c|}
\hline Characteristics & Variables & $\%$ of respondents \\
\hline Gender $(n=164)$ & $\begin{array}{l}\text { Male } \\
\text { Female }\end{array}$ & $\begin{array}{l}76.83 \\
23.17\end{array}$ \\
\hline Age category in years $(n=163)$ & $\begin{array}{l}<25 \\
26-35 \\
36-45 \\
46-55 \\
56-65 \\
>65\end{array}$ & $\begin{array}{l}2.45 \\
3.07 \\
15.95 \\
33.13 \\
32.52 \\
12.88\end{array}$ \\
\hline Marital status $(n=162)$ & $\begin{array}{l}\text { Single } \\
\text { Married } \\
\text { Divorced } \\
\text { Widow } \\
\text { Not specified }\end{array}$ & $\begin{array}{l}11.73 \\
77.78 \\
2.47 \\
5.56 \\
2.47\end{array}$ \\
\hline District Municipalities ( $n=161$ ) & $\begin{array}{l}\text { Sekhukhune } \\
\text { Capricorn } \\
\text { Mopani } \\
\text { Vhembe } \\
\text { Waterberg }\end{array}$ & $\begin{array}{l}27.95 \\
30.43 \\
26.71 \\
4.35 \\
10.56\end{array}$ \\
\hline Land ownership ( $n=163$ ) & $\begin{array}{l}\text { Own } \\
\text { Lease } \\
\text { Communal } \\
\text { Others }\end{array}$ & $\begin{array}{l}50.31 \\
7.36 \\
39.26 \\
3.68\end{array}$ \\
\hline Highest level of education $(n=162)$ & $\begin{array}{l}\text { Primary school } \\
\text { High school } \\
\text { Completed standard } 10 \text { or Grade } 12 \\
\text { Post-secondary } \\
\text { Others or informal education }\end{array}$ & $\begin{array}{l}13.58 \\
27.16 \\
17.90 \\
26.54 \\
14.81\end{array}$ \\
\hline Participation in farming $(n=163)$ & $\begin{array}{l}\text { Full time } \\
\text { Part time } \\
\text { Not defined }\end{array}$ & $\begin{array}{l}63.80 \\
26.99 \\
9.20\end{array}$ \\
\hline Breeds of pigs kept $(n=152)$ & $\begin{array}{l}\text { Large White } \dagger \\
\text { Landrace } \dagger \\
\text { Duroct } \dagger \\
\text { Indigenous or undefined }\end{array}$ & $\begin{array}{l}28.29 \\
10.53 \\
7.24 \\
61.18\end{array}$ \\
\hline Received financial assistance or inputs from government $(n=162)$ & $\begin{array}{l}\text { No } \\
\text { Yes }\end{array}$ & $\begin{array}{l}97.53 \\
2.47\end{array}$ \\
\hline
\end{tabular}

$n$, number of respondents.

$\dagger$, Pig breeds were based only on phenotypic characteristics of the breed types, for example, erect ears, long body, compact shape, brown colour, droopy ears.

TABLE 1b: Characteristics of emerging and small-scale pig farms, Limpopo, South Africa.

\begin{tabular}{|c|c|c|c|c|c|c|c|}
\hline Variables & Mean \pm s.d. & Median & $1 \%$ & $25 \%$ & $75 \%$ & $95 \%$ & $99 \%$ \\
\hline Number of sows per farm $(n=151)$ & $7.4 \pm 7.8$ & 5 & 1 & 3 & 8 & 25 & 40 \\
\hline Number of boars per farm $(n=133)$ & $1.7 \pm 1.4$ & 1 & 0 & 1 & 2 & 5 & 7 \\
\hline Number of days to return to oestrus (sows) $(n=112)$ & $42.9 \pm 46.1$ & 21 & 3 & 14 & 60 & 180 & 210 \\
\hline Average number of piglets weaned/sow per year $(n=115)$ & $4.9 \pm 4.6$ & 3.4 & $<1.0$ & 1.7 & 6.0 & 15.9 & 18.0 \\
\hline
\end{tabular}

$n$, number of respondents; s.d., standard deviation. 


\section{Market}

The majority of the respondents $(82.61 \%)$ preferred or were obliged to sell their pigs at local points and within communities, $9.32 \%$ would sell at the auctions and $14.09 \%$ at formal abattoirs or supermarkets. A total of $40.67 \%$ of the farmers transported their pigs to the slaughter facilities and only $1.33 \%$ of these farmers transported live pigs from different sources in the same vehicle (Table 3). These transportations vary widely between $<50 \mathrm{~km}$ and $400 \mathrm{~km}$, depending on the distance of the major abattoir or auction points (Figure 2).

An evaluation of the price that the farmers received per pig sold revealed that there is a great lack of coordination in pricing and no template exists to standardise sales. For example, a 32-week-old pig (50 kg - $70 \mathrm{~kg}$ ) sells for approximately ZAR 500 compared to ZAR 1200 for a 20-week-old pig ( $\approx 70 \mathrm{~kg})$ in a formal market. It should, however, be emphasised that these pigs often have a high bone-to-meat ratio when compared with those originating from a commercial operation.

Although a good proportion (41.25\%) of the farmers claimed to use concentrates in feeding their pigs, evidence based on the drawn-up checklist contradicted this assertion. It appeared that most of the farmers used kitchen remnants and mixed portions, and only supplemented with vegetables and concentrate feeds (Figure 3). A total of $43.83 \%$ used boreholes as sources of water for their piggery but a proportion $(32.10 \%)$ used village streams and other water sources like rivers $(9.26 \%)$ and municipal water (6.78\%) (Figure 3).

The majority of the farmers (81.76\%) had less than 10 sows (Figure 4, Table 4), and this category of farmers appeared to have the best efficiency index compared to other categories in terms of number of piglets weaned per sow per year $(n$ $=5.19$ ). It appeared that the higher the number of sows per ESSPF, the lower the efficiency of weaning per individual sow on the farm (Table 4).

The average number of days after weaning for sows to return to oestrus in the ESSP farms was 42.9 days (Table 5), but there was significant difference amongst the different categories $(1-10,11-20,21-30,31-40,41-50)(p<0.0001)$. Sows of those farmers with between $1-10$ sows took approximately 49.9 days to return to oestrus, whilst those with between 21 and 30 sows returned to oestrus within 16 days (Table 5, Figure 5); however, some farms with less than 10 sows took up to 210 days for their sows to return to oestrus (Figure 5).

Overall, the level of education was negatively correlated with all of the farm parameters assessed, except the piglets per sow per year, where it had a very poor correlation. The total piglets weaned was positively correlated with the total number of piglets born per sow per year $(39.86 \%)$ and the number of sows on the farm was positively correlated with the total piglets weaned (30.97\%) (Table 6).

\section{Discussion}

The present study's findings and analyses revealed some deficiencies. It is a difficult task to collect critical production parameters where no records exist to validate the collected information, and the farmers' perceptions and recall are the only forms of validation. In the present study, efforts were made to use check questions and interviewees' observational analyses to validate some of the data collected from the farmers. Despite this challenge, the present study has

TABLE 2: Management and health parameters of emerging and small-scale pig farms, Limpopo, South Africa.

\begin{tabular}{|c|c|c|}
\hline Characteristics & Variables & $\%$ of respondents \\
\hline Provide heat source for piglets $(n=157)$ & $\begin{array}{l}\text { No } \\
\text { Yes }\end{array}$ & $\begin{array}{l}92.36 \\
7.64\end{array}$ \\
\hline $\begin{array}{l}\text { Lead reason for pre-weaning mortality of piglets based on } \\
\text { farmer's responses }(n=150)\end{array}$ & $\begin{array}{l}\text { Overlay } \\
\text { Hypothermia } \\
\text { Diarrhoea } \\
\text { Cannibalism } \\
\text { Multiple causes }\end{array}$ & $\begin{array}{l}31.33 \\
12.67 \\
2.67 \\
2.67 \\
62.67\end{array}$ \\
\hline $\begin{array}{l}\text { Disease complex observed in the farm, based on syndrome ( } n \\
=158)\end{array}$ & $\begin{array}{l}\text { Respiratory } \\
\text { Enteric } \\
\text { Skin or integument } \\
\text { Musculoskeletal } \\
\text { Reproductive } \\
\text { Others or mixed infections }\end{array}$ & $\begin{array}{l}6.33 \\
8.86 \\
46.84 \\
5.06 \\
12.66 \\
39.87\end{array}$ \\
\hline Officials contacted in animal disease situation $(n=162)$ & $\begin{array}{l}\text { Veterinarians } \\
\text { Animal health technicians } \\
\text { Extension officers } \\
\text { Cooperative department office } \\
\text { Community leaders } \\
\text { Others }\end{array}$ & $\begin{array}{l}20.37 \\
52.47 \\
17.28 \\
2.47 \\
0.62 \\
14.81\end{array}$ \\
\hline Basic hygienic measures implemented on farms $(n=161)$ & $\begin{array}{l}\text { Hand wash } \\
\text { Fence } \\
\text { Foot bath } \\
\text { Change of clothes } \\
\text { Other measures }\end{array}$ & $\begin{array}{l}8.07 \\
65.84 \\
1.24 \\
0.62 \\
24.22\end{array}$ \\
\hline Vaccination of pigs $(n=162)$ & $\begin{array}{l}\text { No } \\
\text { Yes }\end{array}$ & $\begin{array}{l}98.77 \\
1.23\end{array}$ \\
\hline Medicine frequently used in the farm $(n=158)$ & $\begin{array}{l}\text { Penicillin } \\
\text { Terramycin } \\
\text { Ivermectin } \\
\text { Sulpha medicines } \\
\text { Others (Iron, vitamins, other antibiotics etc.) }\end{array}$ & $\begin{array}{l}5.70 \\
30.38 \\
22.15 \\
1.27 \\
56.33\end{array}$ \\
\hline
\end{tabular}

$n$, number of respondents. 
TABLE 3: Market-related characteristics of emerging and small-scale pig farmers, Limpopo, South Africa.

\begin{tabular}{lll}
\hline Characteristics & Variables & \% of respondents \\
\hline Where pigs are sold? $(n=161)$ & Abattoir & 13.04 \\
& Supermarket or butchery & 1.86 \\
& Auction & 9.32 \\
& Pension points or local markets & 45.96 \\
Source of transport to market $(n=150)$ & Within communities and others & 36.65 \\
& Own & 34.00 \\
& Hired & 5.33 \\
Mean distance from farm to market $(n=151)$ & Shared & 1.33 \\
& Do not transport & 59.33 \\
& $550 \mathrm{~km}$ & 20.00 \\
& $151 \mathrm{~km}-150 \mathrm{~km}$ & 18.71 \\
& $251 \mathrm{~km}-500 \mathrm{~km}$ & 7.10 \\
& $>500 \mathrm{~km}$ & 3.87 \\
& Not applicable & 0.65 \\
\end{tabular}

$n$, number of respondents.
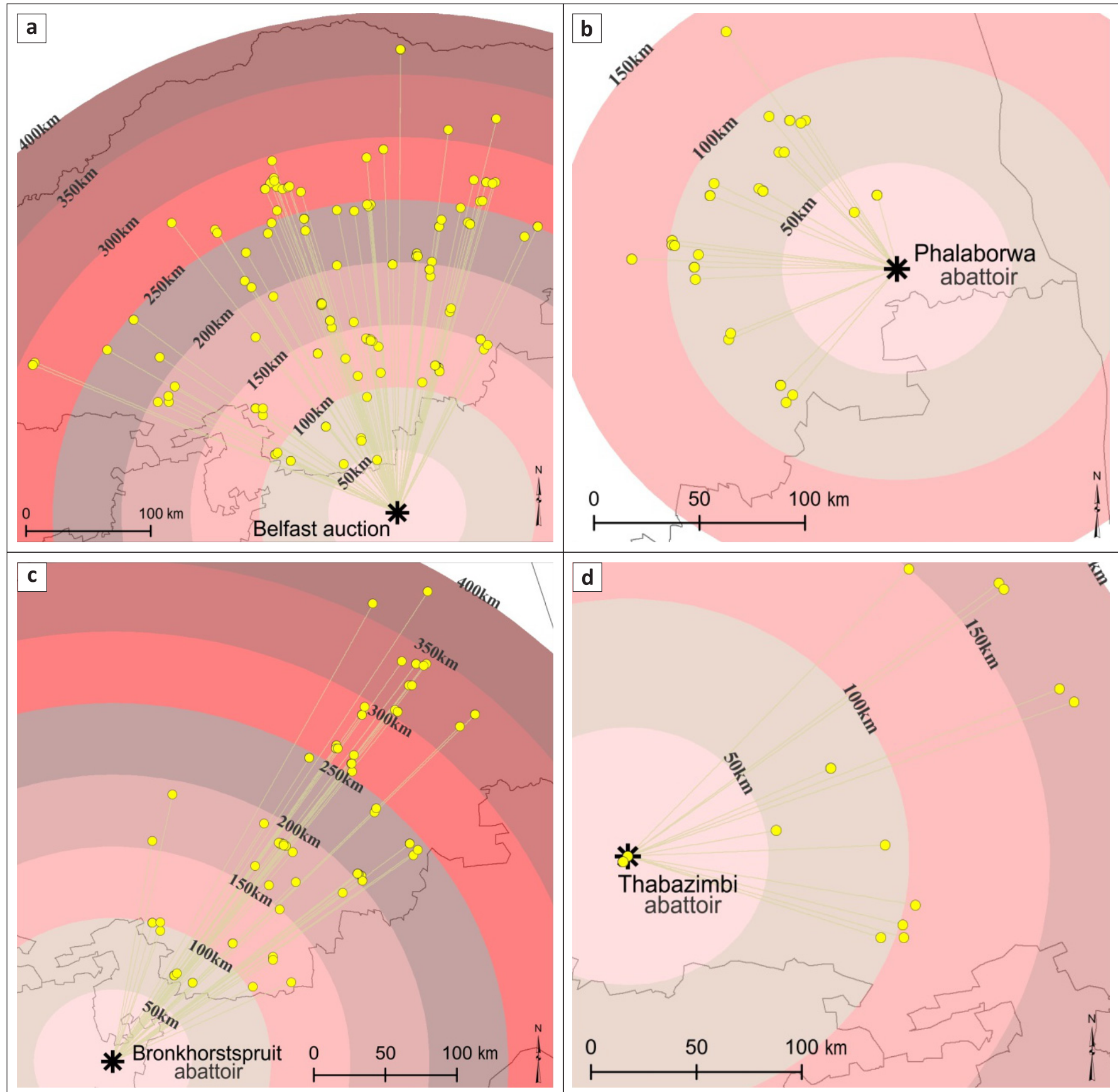

Source: Authors' own construction

FIGURE 2: Distance analyses of movement from farms to major slaughter and marketing points, (a) Belfast auction, (b) Phalaborwa abattoir, (c) Bronkhorstspruit abattoir and (d) Thabazimbi abattoir. 


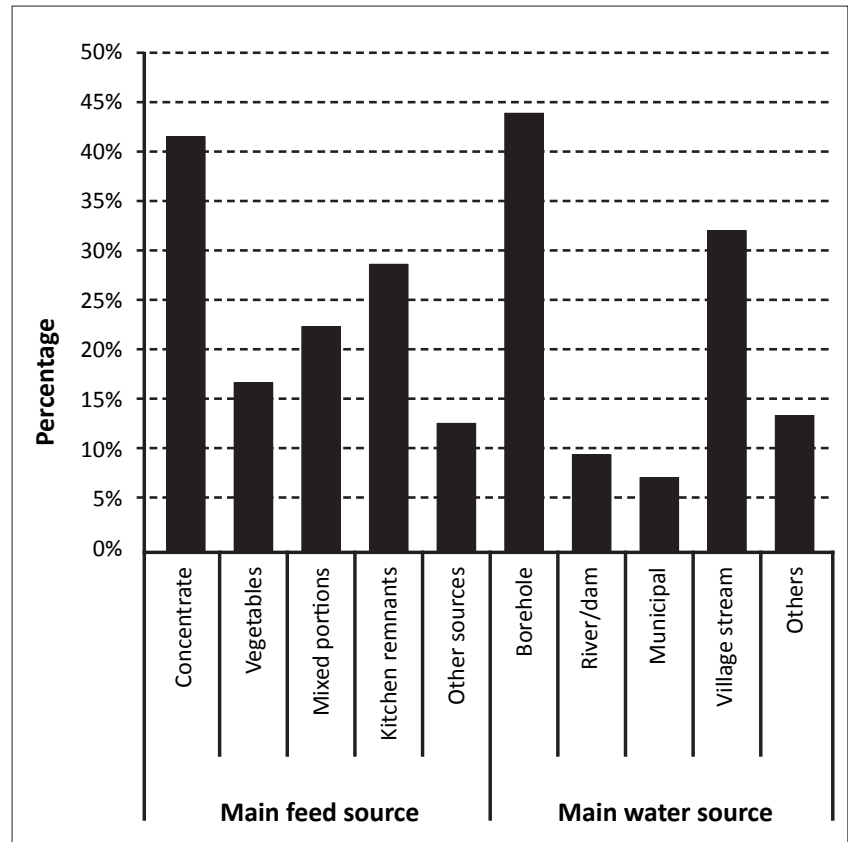

Source: Authors' own construction

FIGURE 3: Main source of feed and water for the pigs.

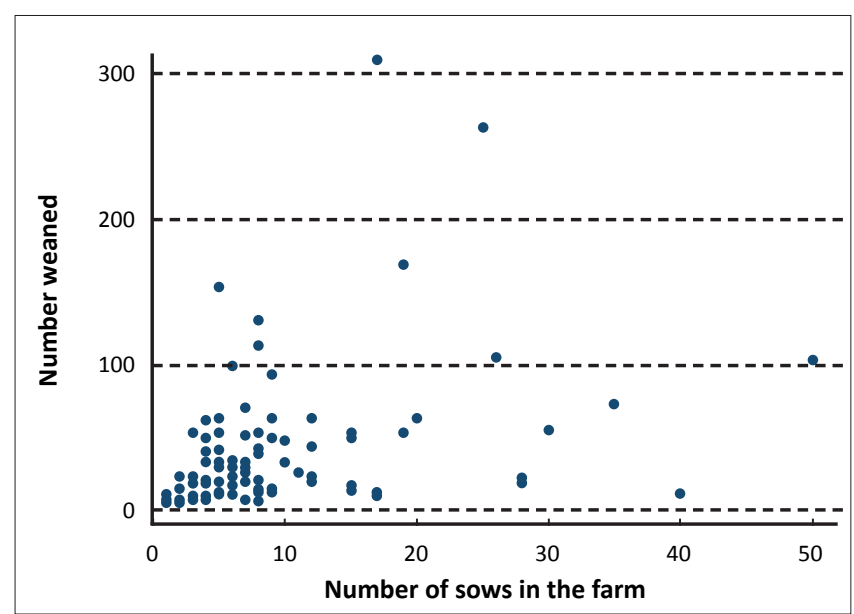

Source: Authors' own construction

FIGURE 4: Evaluation of farm sow population against average number of piglets weaned per year.

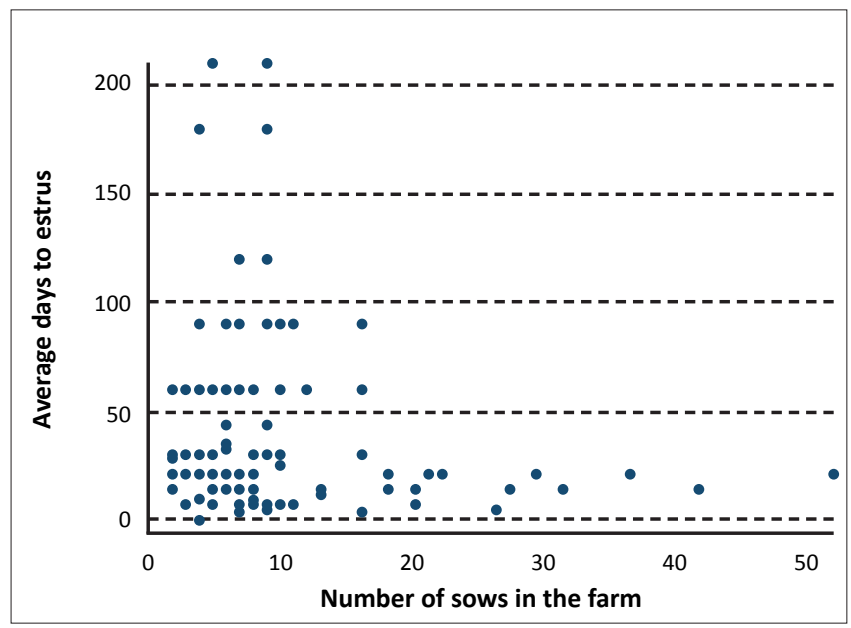

Source: Authors' own construction

FIGURE 5: Evaluation of farm sow population against average number of days to return to oestrus. revealed that most of the ESSPF in Limpopo province are males $(77.00 \%)$, a fact that has raised questions about the issue of women in agriculture and economic empowerment in this sector. It appears that the pig industry has a large imbalance in terms of ownership and gender, and there may be a need to transform the industry and provide more opportunities with a critical focus on women from rural areas. It should be understood, however, that pig farming is labourintensive in terms of input; few women may be willing to get involved in such activities. Whilst gender equity is one of the major standpoints of the land reform policies, to date, female ownership of land and other means of agricultural production, especially in the rural areas, is still viewed with some degree of abhorrence in the region (Anon 2014; Cross \& Hornby 2002; Kalabamu 2006).

The majority of the farmers were older than 45 years of age, which is an indication that the younger generation prefer not to get involved in agriculture but would rather migrate to urban areas in search of salaried jobs (Brooks et al. 2013). This observation may also be an indication of late entry into animal agriculture. A similar trend has been observed in other studies (Oladele, Kolawole \& Antwi 2013; Schembri et al. 2013). Currently, it is widely believed that only the poor become involved in rural farming and that it is not a financially rewarding activity. It is recommended that policies be implimented that encourage younger individuals to be retained in the rural areas at all levels in order to reduce gross emigration to the city, whilst boosting agricultural productivity in the rural areas.

Because pig farming in the rural areas is labour intensive, larger families and married people are at an advantage, as two or more people are involved. The outcome of the present study's analysis indicates that $78.00 \%$ of all respondents were married. The majority of the farmers were also educated up to the end of high school (58.64\%). Previous workers have confirmed that the level of education has a positive relationship on market access (Lubungu, Chapoto \& Tembo 2012). Since farmers with

TABLE 4: Efficiency index of piglets weaned per sow.

\begin{tabular}{llccc}
\hline Sow number & Frequency & \multicolumn{2}{c}{ Mean } & $\begin{array}{c}\text { Efficiency index of } \\
\text { weaning per sow }\end{array}$ \\
\cline { 3 - 5 } & $\begin{array}{c}\text { Sows per farm } \\
(\boldsymbol{n})\end{array}$ & $\begin{array}{c}\text { Piglets weaned } \\
\text { per year }\end{array}$ & \\
\hline $1-10$ & 121 & 5.12 & 26.59 & 5.19 \\
$11-20$ & 17 & 15.46 & 60.20 & 3.89 \\
$21-30$ & 7 & 27.40 & 90.00 & 3.28 \\
$31-40$ & 2 & 37.50 & 39.00 & 1.04 \\
$41-50$ & 1 & 50.00 & 100.00 & 2.00 \\
\hline
\end{tabular}

TABLE 5: Efficiency index of return to oestrus per sow.

\begin{tabular}{llcc}
\hline Sow number & Frequency & $\begin{array}{c}\text { Mean number of days to return to } \\
\text { oestrus per sow } \pm \text { s.e. (days) }\end{array}$ & $\begin{array}{c}95 \% \text { Confidence } \\
\text { interval (days) }\end{array}$ \\
\hline $1-10$ & 86 & $49.9 \pm 5.4$ & $38.4 ; 59.8$ \\
$11-20$ & 15 & $27.5 \pm 6.2$ & $14.2 ; 40.8$ \\
$21-30$ & 6 & $16.0 \pm 2.6$ & $9.3 ; 22.7$ \\
$31-40$ & 2 & $17.5 \pm 3.5$ & $-27.0 ; 62.0$ \\
$41-50$ & 1 & 21.0 & - \\
\hline Total & - & $\mathbf{4 2 . 9} \pm \mathbf{4 . 4}$ & $\mathbf{3 4 . 3} ; \mathbf{5 1 . 6}$ \\
\hline
\end{tabular}

s.e., standard error. 
TABLE 6: Correlation coefficient of sows with certain farm and farmer parameters.

\begin{tabular}{|c|c|c|c|c|c|c|c|}
\hline Parameters & $\begin{array}{l}\text { Highest level of } \\
\text { education }\end{array}$ & Breed of pigs & Number of sows & Days to oestrus & $\begin{array}{l}\text { Piglet per } \\
\text { sow per year }\end{array}$ & $\begin{array}{l}\text { Heat source } \\
\text { present }\end{array}$ & $\begin{array}{l}\text { Total piglets } \\
\text { weaned }\end{array}$ \\
\hline Highest level of education & 1.0000 & - & - & - & - & - & - \\
\hline Breed of pigs & -0.1929 & 1.0000 & - & - & - & - & - \\
\hline Number of sows & -0.0560 & 0.1927 & 1.0000 & - & - & - & - \\
\hline Days to oestrus & -0.1266 & -0.0051 & -0.1603 & 1.0000 & - & - & - \\
\hline Piglet per sow per year & 0.0006 & 0.1744 & 0.2112 & -0.0911 & 1.0000 & - & - \\
\hline Heat source present & -0.1760 & 0.1347 & 0.1981 & 0.0823 & 0.0696 & 1.0000 & - \\
\hline Total piglets weaned & -0.0625 & -0.0163 & 0.3097 & -0.1418 & 0.3986 & 0.1851 & 1.0000 \\
\hline
\end{tabular}

post-secondary education constituted just over a quarter of the total respondents, it is expected that these educated farmers positively influence the market and open access for the less educated ones. It is important to emphasise that the majority of the respondents still kept indigenous and crossbred pigs; these results are comparable with other data from India (70.00\%) (Nath et al. 2013). These indigenous and undefined pigs have been known to under-perform compared with the exotic breeds in terms of litter size, litter weight, birth weight, weaning weight and average daily weight gain, and they often have poor access to veterinary services (Halimani et al. 2010). Extension services must be targeted towards encouraging farmers to adopt the improved breeds of pigs in rural farm operations.

Although the Department of Agriculture, Forestry and Fisheries has made certain provisions available for funding of animal infrastructure in terms of the CASP, only $2.47 \%$ of the respondents have benefited. It will be necessary for government departments to fine-tune agricultural policies and remove unnecessary bottlenecks that impede the development of ESSPF so that planned programmes and policies can reach the targeted beneficiaries. In the current programme, the farmers are supported in terms of provision of 10 sows or a housing unit for $10-50$ sows. A realistic economic model has indicated that farmers will need between 150 and 250 sows to be commercially viable. Whilst the government may not be able to provide this level of support for all the ESSPF, the options of forming them into smaller cooperatives to benefit from economies of scale and become more competitive in terms of input supplies and marketing should be explored (Mashala 2012). In addition, financial institutions should be encouraged to provide lowinterest agricultural financing to farmers with viable projects.

With regard to productivity, analysis indicated that the ESSPF are poorly productive, compared with the commercial operations. They weaned an average of 4.85 piglets per sow per year, which is $19.00 \%$ of the standard for the South African pig industry (26 piglets per sow per year) and it took much longer for the sows to return to oestrus (42.9 days compared with 4-6 days) (Fasina et al. 2012). The statistics generated in the present study are incompatible with economically feasible and viable pig production; there will be a need for a major shift if the ESSP farms are to be commercially viable and sustainable in South Africa. At the same time as consideration is given to these statistics, they should also be carefully examined, since large variations exist between the farmers' operational efficiencies in each category.
Hypothermia is a major source of neonatal and piglet mortalities; it also predisposes piglets to other causes of mortalities including diseases, crushing and starvation (Kammersgaard, Pedersen \& Jørgensen 2011; Pedersen et al. 2012). Hypothermia will significantly reduce the ability of piglets to access the sow and get colostrum within the first $6 \mathrm{~h}-12 \mathrm{~h}$ after birth to meet their nutritional requirements, to benefit from maternal immunity and protect against diseases. Regular supervision in the farrowing house would help to reduce the levels of mortalities in terms of prevention of hypothermia, regular feeding, reducing illnesses and maintaining sow's udder health (Shankar, Madhusudhan \& Harish 2009); this was lacking in the surveyed farms. The great majority of the respondents $(92.36 \%)$ did not provide any heat source and the high level of pre-weaning mortality observed in the farms of ESSPF in Limpopo can be attributed to this situation. Pedersen et al. (2012) confirmed that mortality associated with hypothermia can be seven times more severe in piglets subjected to suboptimal environmental and floor temperatures in the first week of birth (Kammersgaard et al. 2011). Building of simple, but cosy, creeps using local materials can be a cheap but good alternative to using electricity to heat up creep areas. This should potentially reduce hypothermia and encourage piglets to suckle more, with consequent reduction in piglet pre-weaning mortality, and boost performance.

Pigs are exposed to a variety of predisposing factors and pathogens causing diseases. Primary diseases and conditions of concern in the industry include production-limiting diseases, respiratory complexes and lameness-associated problems, amongst others. In the present study's analyses, for ease of recognition by the ESSPF, disease complexes were grouped as syndromes. The disease conditions were grouped as respiratory, enteric, skin or integumentary, musculoskeletal and reproductive syndromes. A total of $46.84 \%$ of the respondents indicated that skin conditions were a major challenge on their farms. Further enquiries from respondents confirmed that the conditions in pigs were observed as scratching, with discoloured or thickened skin, scabs and hair loss, among others, which are indications of sarcoptic mange (Arends, Stanislaw \& Gerdon 1990). Mange significantly depresses growth rate and feed efficiency, and it is expected that a considerable loss in days-to-market prevails amongst the pigs from these farms for that reason. Many of the farmers sell their pigs at an average of 8 months, a loss of about 90 days compared to the commercial operations. A total of $22.15 \%$ of the respondents mentioned ivermectin as a frequently used medicine on the farms. It is particularly concerning that terramycin is used routinely by about $30.00 \%$ 
of the farmers, without proper diagnosis and consideration of its consequences. It is recommended that a communityspecific farm-health plan be constructed to target this group, using state veterinarians and animal health technicians. Such health plans must include messages on the importance of vaccination, antibiotic abuse and biosecurity, areas, where serious deficiencies were observed amongst the respondents (Food and Agriculture Organization [FAO] 2010; Fasina et al. 2012). Vaccination against very important productionlimiting diseases of pigs in South Africa (parvovirus, leptospirosis and erysepelas, as well as Escherichia coli) must be included in such protocols. Similarly, it would be beneficial to use vaccines on a cost-sharing basis between farmers.

Since the farmers use the services of animal health technicians, extension officers and veterinarians, there is a need for coordination among these professionals to maximise the impact of state veterinary extension services and block loopholes that may exist with individual efforts. Data, which are comparable to the present study's statistics, about increased reliance on technicians rather than the veterinarians by ESSPF, has been reported elsewhere (Alawneh et al. 2014). It should be emphasised that disease complexes among the ESSP farms pose major risks to the commercial operations. Therefore the inclusion of private veterinarians and large commercial farms in sponsoring veterinary extension services amongst these individuals whilst serving the role of mentors and patrons must be critically evaluated. The extension messages must also target how market access can be created for these farmers and a suitable grading system that will encourage them to maximise productivity and move towards good farming practices. The role of veterinary extension and the use of multiple professionals to meet the challenges of animal health services have been emphasised previously (Hernández-Jover et al. 2008; Mockshell, Ilukor \& Birner 2014). The determinants of cooperation and referrals between paraprofessionals and veterinarians have been previously identified to include mobile phone ownership, training, cumulative annual assessment, and membership of paraprofessional bodies and association (Ilukor, Nielsen \& Birner 2014). It is necessary to facilitate inter-professional relationships amongst animal health service providers in rural South Africa by provision of the identified facilities.

Nutrition and feeding are very important components of animal production and health; in the present study, it was concluded that the ESSPF are more likely to swillfeed the pigs, with potential consequences of spreading diseases, including exotic pig diseases like classical swine fever, foot-and-mouth disease and porcine respiratory and reproductive syndrome. Similarly, since the swill is not evaluated for its nutritional qualities, it becomes difficult to assess whether this feed meets the nutritional requirement of the different classes of pigs on the farms. It is probable that the weaning and growing pigs are underfed and this is responsible for their taking longer to reach appropriate market weights (Manchidi 2009; Viljoen 1993).

Water is a critical resource in any pig production unit, as it is required for cleaning the pens, drinking purposes and cooling the pigs. In many of the farm units included in the present study, pigs get water only twice a day, whilst certain piggeries only supply water every other day. Limited access to water has negative effects on pigs, as it retards their growth potential and affects many other biochemical processes, resulting in conditions such as salt toxicity (Manchidi 2009). Based on estimation, the greater the distance between the household or production site and water source, the higher the probability of not providing water regularly. Since about $45.06 \%$ of the farmers only depended on village streams or other distant sources for water, pigs reared under these conditions are likely to suffer degrees of water deprivation. However if a farmer wants to proceed with a regular supply of feed and water, despite the distance between the farm and sources of supplies, a higher capital cost will be incurred and realistic profitable operation will become more difficult (Mabuza \& Ngubane 2010).

Finally, the South African pig retail industry is broadly classified into a dual market structure: the high-value markets (processors and supermarkets) for commercial pig farmers and the low-value markets (local auctions, pension pay points for the ESSPF). Whilst the high-value markets pay premium prices for quality products, the emerging smallscale pig farmers get paid below the market values for their pigs (Antwi \& Seahlodi 2011). The present study's findings confirmed this assertion, since no coordinated pricing and standardised sale template exists for this category of farmers. The use of extension services to improve sectoral marketing and possible formation into cooperatives is critical.

\section{Conclusions}

Certain factors have been identified that limit the improvement in efficiency of ESSPF and inhibit pig production and health. Correction of these identified factors, as well as the multi-disciplinary role played by all the actors in the animal industry, will improve the situation of pig farming in Limpopo and reduce the burden of disease in South Africa.

\section{Acknowledgements}

The authors' acknowledge: the Limpopo Department of Agriculture for providing funds for this survey as part of a postgraduate programme; the Director of Veterinary Services in Limpopo province, Dr Mampane and his team of managers in the districts, and all the veterinary officials for their help with collection of data in their respective districts. The Department of Production Animal Studies and the Faculty of Veterinary Science, Onderstepoort partially supported this work with funds and permitted the use of their resources for postgraduate training. Mrs Ingrid Booysen of the Department of Geography, Geoinformatics and Meteorology kindly produced the maps.

\section{Competing interests}

The authors declare that they have no financial or personal relationship(s) that may have inappropriately influenced them in writing this article. 


\section{Authors' contributions}

J.M.M. (University of Pretoria), B.T.S. (University of Pretoria) and F.O.F. (University of Pretoria) formulated the hypothesis and questionnaire design and validation; L.A.M.G.v.L. (University of Pretoria) and F.O.F. evaluated data and provided guidance; B.T.S. and F.O.F. supervised the study; J.M.M. performed field data collection and data entry; F.O.F. performed statistical analysis; J.M.M., F.O.F., L.A.M.G.v.L. and B.T.S. interpreted the data and wrote the manuscript. All authors read and approved the manuscript for submission. The lead author is an M Med Vet Suill. candidate in the Department of Production Animal Studies, Faculty of Veterinary Science, University of Pretoria.

\section{References}

Alawneh, J.I., Barnes, T.S., Parke, C., Lapuz, E., David, E., Basinang, V. et al., 2014 'Description of the pig production systems, biosecurity practices and herd health providers in two provinces with high swine density in the Philippines' Preventive Veterinary Medicine 114, 73-87. http://dx.doi.org/10.1016/j prevetmed.2014.01.020

Anon, 2014, Women, Patriarchy and Land Reform in South Africa, Chapter 10, viewed 06 March 2014, from http://wiredspace.wits.ac.za/bitstream/ handle/10539/275/22_chapter10.pdf?sequence=22

Antwi, M. \& Seahlodi, P., 2011, 'Marketing constraints facing emerging small-scale pig farmers in Gauteng province, South Africa', Journal of Human Ecology 36, 37-42.

Arends, J.J., Stanislaw, C.M. \& Gerdon, D., 1990, 'Effects of sarcoptic mange on lactating swine and growing pigs', Journal of Animal Science 68(6), 1495-1499.

Boshoff, C.I., Bastos, A.D.S., Gerber, L.J. \& Vosloo, W., 2007, 'Genetic characterisation of African swine fever viruses from outbreaks in southern Africa (1973 1999)', Veterinary Microbiology 121, 45-55. http://dx.doi.org/10.1016/j. vetmic.2006.11.007

Brooks, K., Zorya, S., Gautam, A. \& Goyal, A., 2013, 'Agriculture as a sector of opportunity for young people in Africa', The World Bank Policy Research Working Paper 6473, viewed 04 September 2014, from http://www.ypard.net/sites/ypard. net/files/Agriculture\%20opportunity\%20youth\%20africa.pdf

Chikazunga, D., Jordaan, D., Biénabe, E. \& Louw, A., 2007, 'Patterns of restructuring food markets in South Africa: The case of fresh produce supply chains', Proceeding of the 2nd International Conference of the African Association of Agricultura Economists AAAE, Accra, Ghana, 20-22 August 2007, pp. 53-55.

Cross, C. \& Hornby, D., 2002, 'Opportunities and obstacles to women's land access in South Africa', viewed 06 March 2014, from file:///C:/Users/User/Downloads/ landgender.pdf

Department of Agriculture, Forestry and Fisheries (DAFF), 2012

Dietze, K., 2011, 'Pigs for Prosperity', in Diversification Booklet Number 15, p. 58, Food and Agriculture Organization of the United Nations, Rome.

Food and Agriculture Organization (FAO), 2010, Good Practices for Biosecurity in the Pig Sector - Issues and Options in Developing and Transition Countries, Animal Production and Health Paper 169, Food and Agriculture Organization of the United Nations, Rome.

Food and Agriculture Organization Corporate Statistical Database (FAOSTAT), 2014 Pig population and pork production (South Africa), viewed 04 June 2014, from http://faostat.fao.org/site/573/DesktopDefault.aspx?PagelD=573\#anco

Fasina, F.O., Lazarus, D.D., Spencer, B.T., Makinde, A.A. \& Bastos, A.D.S., 2012, 'Cost implications of African swine fever in smallholder farrow-to-finish units: economic benefits of disease prevention through biosecurity', Transboundary and Emerging Diseases 59, 244-255. http://dx.doi.org/10.1111/j.1865-1682.2011.01261.x
Halimani, T.E., Muchadeyi, F.C., Chimonyo, M. \& Dzama, K., 2010, 'Pig genetic resource conservation: The Southern African perspective', Ecological Economics 69, 944951. http://dx.doi.org/10.1016/j.ecolecon.2010.01.005

Hernández-Jover, M., Schembri, N., Toribio, J.A.L.M.L. \& Holyoake, P.K., 2008, 'Biosecurity risks associated with current identification practices of producers trading live pigs at livestock sales', Animal 2, 1692-1699. http://dx.doi. org/10.1017/S1751731108003066

llukor, J., Nielsen, T. \& Birner, R., 2014, 'Determinants of referrals from paraprofessionals to veterinarians in Uganda and Kenya', Preventive Veterinary Medicine, n.p. http://dx.doi.org/10.1016/j.prevetmed.2014.02.009

Ironkwe, M.O. \& Amefule, K.U., 2008, 'Appraisal of indigenous pig production and management practices in Rivers State, Nigeria', Journal of Agriculture and Social Research 8, 1-7.

Kalabamu, F., 2006, 'Patriarchy and women's land rights in Botswana', Land Use Policy 23, 237-246. http://dx.doi.org/10.1016/j.landusepol.2004.11.001

Kammersgaard, T.S., Pedersen, L.J. \& Jørgensen, E., 2011, 'Hypothermia in neonatal piglets: Interactions and causes of individual differences', Journal of Anima Science 89, 2073-2085. http://dx.doi.org/10.2527/jas.2010-3022

Lubungu, M., Chapoto, A. \& Tembo, G., 2012, Smallholder Farmers Participation in Livestock Markets: The Case of Zambian Farmers, 26a Middleway, Kabulonga, Lusaka, Zambia.

Mabuza, M.L. \& Ngubane, T.P, 2010, 'Factors influencing investment in commercial pig production on Swazi Nation Land', Bulletin of Animal Health and Production in Africa 58, 79-87. http://dx.doi.org/10.4314/bahpa.v58i1.57065

Manchidi, M.J., 2009, 'An evaluation of small-scale piggeries in Limpopo Province, South Africa', unpublished thesis for Master of Philosophy, Stellenbosch University.

Mashala, P., 2012, 'Helping small-scale pig farmers', Farmers Weekly, 30 August, 2012.

Mergenthaler, M., Weinberger, K. \& Qaim, M., 2009, 'The food system transformation in developing countries: A disaggregate demand analysis for fruits and vegetables in Vietnam', Food Policy 34, 426-436. http://dx.doi.org/10.1016/j foodpol.2009.03.009

Mockshell, J., llukor, J. \& Birner, R., 2014, 'Providing animal health services to the poor in Northern Ghana: Rethinking the role of community animal health workers?', Tropical Animal Health and Production 46, 475-480. http://dx.doi.org/10.1007/ s11250-013-0518-9

Nath, B.G., Pathak, P.K., Ngachan, S.V., Tripathi, A.K. \& Mohanty, A.K., 2013, 'Characterization of smallholder pig production system: Productive and reproductive performances of local and crossbred pigs in Sikkim Himalayan region', Tropical Animal Health and Production 45, 1513-1518. http://dx.doi. org/10.1007/s11250-013-0391-6

Oladele, O.I., Kolawole, A.E. \& Antwi, M.A., 2013, 'Knowledge of biosecurity among livestock farmers along border villages of South Africa and Botswana' Asian Journal of Animal and Veterinary Advances 8(7), 874-884. http://dx.doi. org/10.3923/ajava.2013.874.884

Pedersen, L.J., Malmkvist, J., Kammersgaard, T. \& Jørgensen, E., 2012, 'Avoiding hypothermia in neonatal pigs: Effect of duration of floor heating at different room temperature', Journal of Animal Science 91(1), 425-432. http://dx.doi. org/10.2527/jas.2011-4534

Raman, K.V., Sanghi, N.K. \& Chambers, R., 1989, 'Part 2: Institutions and practical change', in R. Chambers, A. Pacey \& L.A. Thrupp (eds.), Farmer First: Farmer Innovation and Agricultural Research, pp. 55-105, IT Publications, London.

Schembri, N., Hernandez-Jover, M., Toribio, J.A.L.M.L. \& Holyoake, P.K., 2013, 'Demographic and production practices of pig producers trading at saleyards in eastern Australia', Australian Veterinary Journal 91, 507-516. http://dx.doi. org/10.1111/avj.12131

Shankar, B.P., Madhusudhan, H.S. \& Harish, D.B., 2009, 'Pre-weaning mortality in pig - causes and management', Veterinary World 2(6), 236-239.

Steyn, A.G.W., Smit, C.F., Du Toit S.H.C. \& Strasheim, C., 1994, Modern Statistics in Practice, Van Schaik Publishers, Pretoria.

Thrusfield, M., 1995, Veterinary Epidemiology, 2nd edn., Blackwell Science Ltd., London.

Viljoen, J., 1993, 'Nutrient requirements of growing pigs - birth to marketing', in E.H. Kemm (ed.), Pig Production in South Africa, Bulletin 427, pp. 66-75, ARC-Irene Animal Production Institute, Pretoria. 


\section{Appendix 1}

\section{A semi-structured questionnaire.}

The University of Pretoria, Faculty of Veterinary Science is conducting an investigation into the reasons resulting in poor production among the emerging small scale pig farmers of the Limpopo Province of the Republic of South Africa.

You have been selected as one of our respondent to kindly answer the questions with your consent and personal experience. The answers provided will be kept strictly confidential and will be used for research and planning purposes. No personal details will be revealed.

Thank you for your cooperation.

Name:

Signature:

Date:

\section{SECTION A:}

PERSONAL INFORMATION

\section{Q1: Name and Surname}

\section{Q2: Gender}

\begin{tabular}{|l|l|}
\hline Male & \\
\hline Female & \\
\hline
\end{tabular}

\section{Q3: Age category}

\begin{tabular}{|l|l|}
\hline$<25$ Years & \\
\hline $25-35$ Years & \\
\hline $35-45$ Years & \\
\hline $45-55$ Years & \\
\hline $55-65$ Years & \\
\hline Other & \\
\hline If 'Other' please specify: & \\
\end{tabular}

\section{Q4: 4. Marital status}

\begin{tabular}{|l|l|}
\hline Single & \\
\hline Married & \\
\hline Divorced & \\
\hline Widow & \\
\hline
\end{tabular}

Q5: District municipality

\section{Q6: Local municipality}

\section{Q7: Farm name and area}

\section{Q8: Farm geographic location and co-ordinates}

Q9: Do you own this land that you use for farming?

\begin{tabular}{|l|l|}
\hline Own land & \\
\hline Lease & \\
\hline Communal & \\
\hline Other & \\
\hline If 'Other' please specify: & \\
\end{tabular}

\section{Q10: Participation in pig farming?}

\begin{tabular}{|l|l|}
\hline Full-time pig farmer & \\
\hline Part-time pig farmer & \\
\hline Other & \\
\hline If 'Other' please specify: \\
\hline
\end{tabular}

\section{Q11: What is your vision on farming?}

\begin{tabular}{|l|l|}
\hline Commercial farming & \\
\hline Retire & \\
\hline Other enterprises & \\
\hline Other & \\
\hline If 'Other' please specify: & \\
\hline
\end{tabular}

\section{Q12: Do you have other people involved in farming?}

\begin{tabular}{|l|l|}
\hline Son & \\
\hline Daughter & \\
\hline Family & \\
\hline Cooperative & \\
\hline Employees & \\
\hline
\end{tabular}

\section{Q13: What is your highest level of education?}

\begin{tabular}{|l|l|}
\hline Primary school & \\
\hline High school & \\
\hline Matric & \\
\hline Graduate & \\
\hline Other & \\
\hline If 'Other' please specify: & \\
\end{tabular}

\section{SECTION B:}

\section{MANAGEMENT OR PRODUCTION}

\section{Q1: What kind of pigs do you have in your farm?}

\begin{tabular}{|l|l|}
\hline Duroc & \\
\hline Landrace & \\
\hline Large White & \\
\hline Other & \\
\hline If 'Other' please specify: & \\
& \\
\hline
\end{tabular}


Q2: How many female pigs are used for breeding?

\begin{tabular}{|l|l|}
\hline 1 to 5 Pigs & \\
\hline 5 to 15 Pigs & \\
\hline 15 to 30 Pigs & \\
\hline 30 to 45 Pigs & \\
\hline 45 to 50 Pigs & \\
\hline
\end{tabular}

Q3: How many days does it take your sow to go back to heat after weaning?

\begin{tabular}{|l|l|}
\hline 3 to 7 Days & \\
\hline 7 to 24 Days & \\
\hline 24 to 30 Days & \\
\hline 30 to 60 Days & \\
\hline$>60$ Days & \\
\hline
\end{tabular}

Q4: How many boars do you have in your farm?

\begin{tabular}{|l|l|}
\hline $1-2$ Boars & \\
\hline $2-4$ Boars & \\
\hline $5-6$ Boars & \\
\hline $6-7$ Boars & \\
\hline $7-8$ Boars & \\
\hline
\end{tabular}

Q5: How many female pigs are replaced or added every year?

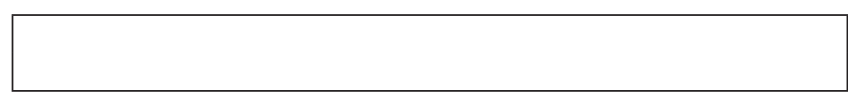

Q6: How many piglets were born per sow per farrowing in 2012?

\begin{tabular}{|l|l|}
\hline $1-4$ piglets & \\
\hline $4-8$ piglets & \\
\hline $8-12$ piglets & \\
\hline $12-16$ piglets & \\
\hline
\end{tabular}

Q7: How many piglets are born dead per sow?

Q8: How many piglets' die before weaning?

Q9: Why do piglets die before weaning?

\begin{tabular}{|l|l|}
\hline Laid on & \\
\hline Coldness & \\
\hline Diarrhoea & \\
\hline Dog eat them & \\
\hline Other & \\
\hline If 'Other' please specify: & \\
& \\
\hline
\end{tabular}

Q10: How do you keep the piglets warm during winter?

Q11: How many piglets did you wean in 2012?
Q12: How many pigs did you sell, slaughter or give away in 2012?

\section{SECTION C:}

\section{HEALTH PLAN}

Q1: List the most important disease complex experienced in your farm?

\begin{tabular}{|l|l|}
\hline Respiratory diseases complex & \\
\hline Enteric diseases or diarrhoea & \\
\hline Skin diseases & \\
\hline Lameness or muscular problems & \\
\hline Other & \\
\hline If 'Other' please specify: & \\
& \\
\hline
\end{tabular}

Q2: What are the biosecurity measures that you have in your farms?

\begin{tabular}{|l|l|}
\hline Hand-washing & \\
\hline Fence & \\
\hline Footbath & \\
\hline Change overalls & \\
\hline Other & \\
\hline If 'Other' please specify: & \\
& \\
& \\
\end{tabular}

\section{Q3: Do you vaccinate your pigs?}

\begin{tabular}{|l|l|}
\hline Yes & \\
\hline No & \\
\hline
\end{tabular}

Q4: If yes, which vaccines / drugs do you use in your farm?

\begin{tabular}{|l|l|}
\hline Farrowsure & \\
\hline Teramycin & \\
\hline Ivermectin & \\
\hline Dip stuff & \\
\hline Other & \\
\hline If 'Other' please specify: & \\
& \\
& \\
\end{tabular}

Q5: What medicine do you use to treat the diseases?

\begin{tabular}{|l|l|}
\hline Penicillin & \\
\hline Teramycin & \\
\hline Ivermectin & \\
\hline Sulpha-drugs & \\
\hline Other & \\
\hline If 'Other' please specify: & \\
& \\
& \\
\end{tabular}


SECTION D:

HOUSING

Q1: Did you receive any financial help to build these pig houses?

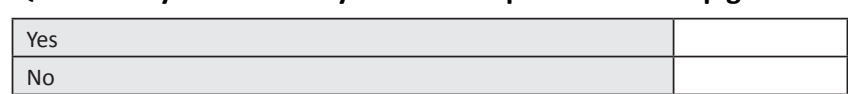

Q2: If yes, what kind of help did you receive?

Q2:

Q3: How many farrowing pens do have in your farm?

Q4: How many pens do you have for the boars?

Q5: How many pens do you have for the weaners?

Q6: How many pens do you have for the growers?

\section{SECTION E:}

\section{FEEDING STRATEGIES}

\section{Q1: What type of feed do you feed your pigs?}

\begin{tabular}{|l|l|}
\hline Bought feed & \\
\hline Vegetables & \\
\hline Dry meal and Kitchen food & \\
\hline Kitchen food & \\
\hline Other & \\
\hline If 'Other' please specify: \\
\\
\end{tabular}

Q2: Where do you buy your feed?

Q3: How much feed do you give your pigs every day?

\begin{tabular}{|l|l|}
\hline Sows & \\
\hline Boars & \\
\hline Weaners & \\
\hline Growers & \\
\hline
\end{tabular}

\section{Q4: Where do you get water for the pigs?}

\begin{tabular}{|l|l|}
\hline Own borehole & \\
\hline River or dam & \\
\hline Municipality water & \\
\hline Village water & \\
\hline Other & \\
\hline If 'Other' please specify: & \\
\end{tabular}

\section{SECTION F:}

\section{MARKETING STRATEGY}

Q1: Where do you sell your pigs?

\begin{tabular}{|l|l|}
\hline Abattoir & \\
\hline Supermarket or Butchery & \\
\hline Auctions & \\
\hline Pension points or local market & \\
\hline Other & \\
\hline If 'Other' please specify: & \\
\end{tabular}

Q2: How many pigs did you sell in 2012?

Q3: At which age did you sell your pigs?

Q4: How much money do you get for every pig?

\begin{tabular}{|l|l|}
\hline R200-R300 & \\
\hline R300-R500 & \\
\hline R500-R800 & \\
\hline R800 - R1200 & \\
\hline Other & \\
\hline If 'Other' please specify: & \\
& \\
\hline
\end{tabular}

\section{Q5: How do you transport your pigs to the market?}

\begin{tabular}{|l|l|}
\hline Own transport & \\
\hline Hired transport & \\
\hline Shared transport & \\
\hline Other & \\
\hline If 'Other' please specify: & \\
\end{tabular}

Q6: What is the distance between your piggery and the market?

\begin{tabular}{|l|l|}
\hline Less than $50 \mathrm{~km}$ & \\
\hline $50 \mathrm{~km}-150 \mathrm{~km}$ & \\
\hline $150 \mathrm{~km}-250 \mathrm{~km}$ & \\
\hline $250 \mathrm{~km}-500 \mathrm{~km}$ & \\
\hline$>500 \mathrm{~km}$ & \\
\hline
\end{tabular}

